${ }^{3}$ Sparkes RS, Ling SM, Muller H. Ring 10 chromosome: 46,XX,r(10) (p15q26). Hum Genet 1978;43:341-5.

4 McKusick VA. In: Mendelian inheritance in man. 5th ed. Baltimore: Johns Hopkins University Press, 1978.

Requests for reprints to Dr R Tsukino, Department of Pediatrics, Wakayama Medical College, 9Kyubancho, Wakayama, Japan.

\section{Hypomelanosis of Ito with triphalangeal thumbs}

SUMMARY A black female with abnormal skin pigmentation, similar to that seen in hypomelanosis of Ito, and triphalangeal thumbs is presented. This association has not previously been reported.

Incontinentia pigmenti achromians, or hypomelanosis of Ito, a neurocutaneous syndrome which includes hypopigmented areas of the skin in whorls, streaks, and patches, occurring either bilaterally or unilaterally, was first described in 1952 by Ito. ${ }^{1}$

This syndrome has been associated with several other abnormalities including mental retardation and epilepsy. ${ }^{2}$ Ocular and musculoskeletal anomalies have also been reported. ${ }^{3}$ A black girl with the typical skin lesions of hypomelanosis of Ito and triphalangeal thumbs, a previously unreported finding, is presented here.

\section{Case report}

A $10 \frac{1}{2}$-year-old black girl was referred to the Genetics Screening and Counseling Service with a diagnosis of the Holt-Oram syndrome. She was the product of a normal term pregnancy and spontaneous vaginal delivery. Birthweight was $2640 \mathrm{~g}$, and length was $47 \mathrm{~cm}$. The mother states that the patient had the depigmented areas at birth but that there were no other abnormalities of the skin, such as bullae. She had poor weight gain in the first few months and was admitted to hospital for evaluation of failure to thrive. The diagnosis of the Holt-Oram syndrome was suggested after a grade 2/6 murmur was noted. She also showed significant developmental delay at that time. She continued to develop slowly and started walking between 5 and 6 years of age. At 10 years 4 months, she was estimated to be functioning at the 2-year-old level. The family history was negative for any similar findings, skin lesions, or mental retardation.

Physical examination at $10 \frac{1}{2}$ years (fig 1) showed a very small, unusual-looking black girl with severe mental retardation. The height was $108 \mathrm{~cm}$, less than the $3 \mathrm{rd}$ centile for age. The weight was $17 \cdot 7 \mathrm{~kg}$, less than the 3rd centile for age. Head circumference was $49 \mathrm{~cm}$, below the 2 nd centile for age. Other abnormal findings included ocular hypertelorism with an intercanthal distance of $3.9 \mathrm{~cm}$ and an outer orbital distance of $10 \mathrm{~cm}$, a small pit in the superior helical region of the right ear, and a small ear tag on the left. The neck appeared short with limitation of rotation. There was kyphosis and scoliosis. The

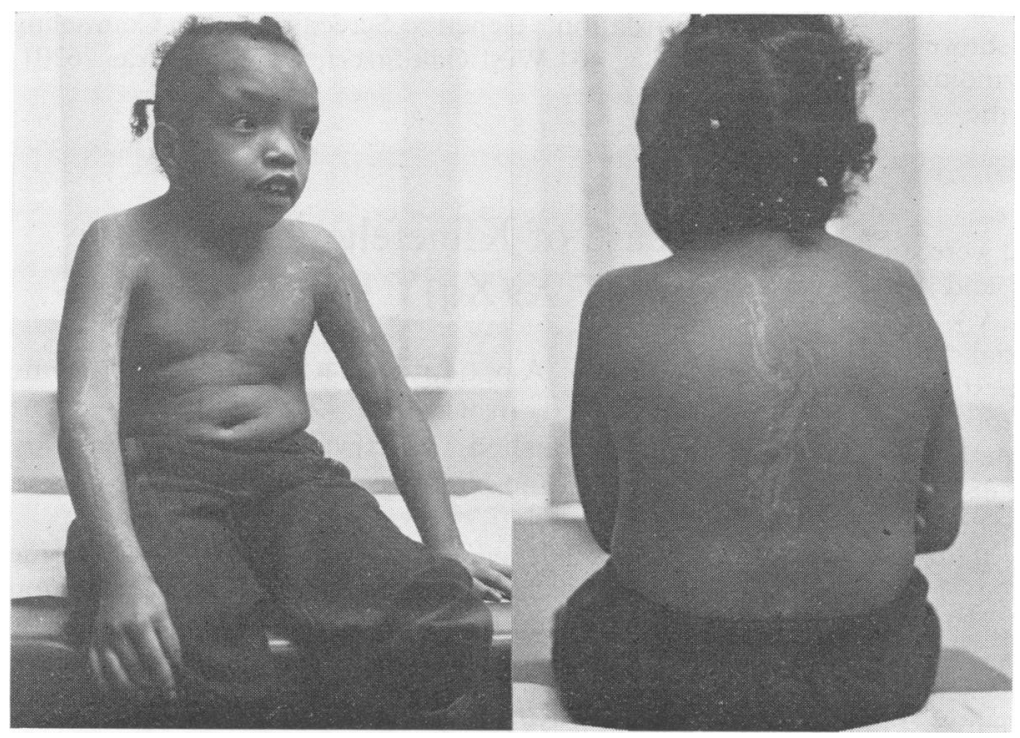

FIG 1 Proband at age $10 \frac{1}{2}$. 


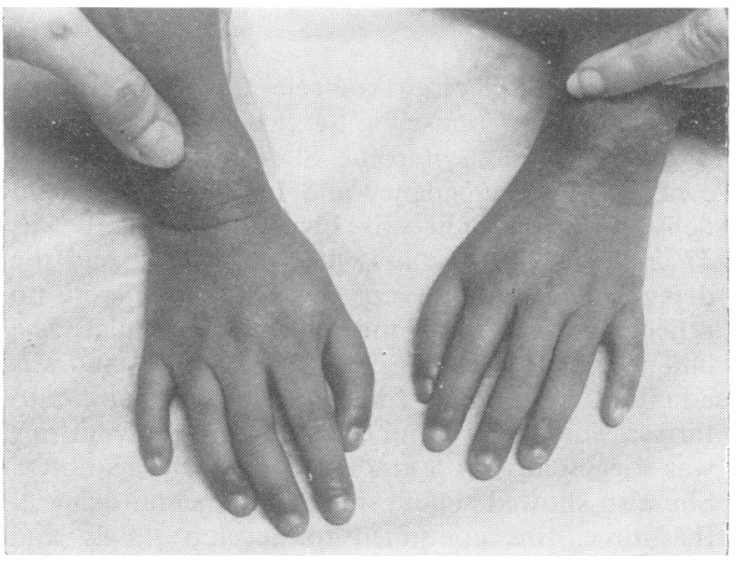

FIG 2 Hands of the proband at age $10 \frac{1}{2}$.

hands were unusual-looking with triphalangeal thumbs bilaterally and mild clinodactyly of the fifth finger bilaterally (fig 2). The thumbs were not opposable. The hallux was short with probable short metatarsal. No other skeletal abnormalities were noted. The skin showed many areas of depigmentation in linear patterns as well as whorls. Neurological examination showed mental retardation, but no specific defects.

\section{LABORATORY STUDIES}

Metabolic screening including routine urine analysis and urine screens for homocystine, ketones, and mucopolysaccharides were normal. A haematological evaluation, including white blood cell count, was normal with a haematocrit of 39 and a haemoglobin of $12 \cdot 8$. Chromosome analysis showed a normal 46,XX karyotype using multiple banding techniques. There was a large marker on the short arm of chromosome 22 .

\section{DERMATOGLYPHS}

The dermatoglyphs of the proband were studied. The digital patterns showed 6 arches and 4 loops. (R: $\mathrm{A}, \mathrm{A}, \mathrm{A}, \mathrm{Lu}, \mathrm{Lu} ; \mathrm{L}$ : $\mathbf{L r}, \mathrm{Lu}, \mathbf{A}, \mathrm{A}, \mathrm{A}$,$) with a total$ finger ridge count of 72 . The axial $t$ distance was raised $(R, 33 \% ; L, 28 \%)$ suggesting a $t^{\prime}$ to $t^{\prime \prime}$ placement of the triradius. Several palmar triradii were absent, and two interdigital triradii were present. Both palms showed some dissociation, open thenar patterns, and $\mathrm{Au}$ hypothenar patterns. Palmar mainline formulas were: $\mathrm{R}$ : Oid0.5".1.11; L: Oid0.5"0.0.11.

\section{Discussion}

This patient shows skin findings that are compatible with the diagnosis of hypomelanosis of Ito. In $\stackrel{\mathbb{D}}{\leftrightarrows}$ addition, she has the unusual finding of triphalangeal $\stackrel{\mathbb{P}}{\rightarrow}$ thumbs. This hand abnormality has been described in other syndromes, such as the Holt-Oram synrome, Fanconi's anaemia, and as an isolated defect. ${ }^{4} 5$ However, this patient's skin pigmentation, mental retardation, hypertelorism, and the abnormal thumbs $\vec{\nabla}$ are most likely the result of a single pathological $\varrho$ process rather than the simultaneous occurrence of $\nRightarrow$ two or more unrelated syndromes or congenital $\vec{\circ}$ defects. This may represent a variant of the syndrome of hypomelanosis of Ito or possibly a new $\vec{\omega}$ syndrome involving triphalangeal thumbs.

M K Kukolich, B W Althaus, M V R FreEMAN, AND R C LEWANDOWSKI Texas Department of Mental Health and Mental Retardation, Genetics Screening and Counseling Service, 404 West Oak Street, Denton, Texas 76201, USA

\section{References}

1 Ito M. Studies of melanin. XI. Incontinentia pigmenti achromians. Tohoku J Exp Med 1952;55(suppl):57-9.

2 Schwartz MF, Esterly NB, Fretzin DF, Pergament E, Rozenfeld IH. Hypomelanosis of Ito (incontinentia pigmenti achromians). J Pediatr 1977;90:235-40.

3 Jelinek, JE, Bart RS, Schiff GM. Hypomelanosis of Ito. Arch Dermatol 1973;107:596-601.

4 Smith DW. Recognizable patterns of human malformation. Philadelphia: WB Saunders, 1976.

5 Swanson AB, Brown KS. Hereditary triphalangeal thumb. J Hered 1962;53:259-65.

Requests for reprints to Dr Mary K Kukolich, Texas Department of Mental Health and Mental Retardation, Genetics Screening and Counseling Service, 404 West Oak Street, Denton, Texas 76201, USA.

\section{A case of Klinefelter's syndrome with $47, \mathrm{Xi}(\mathrm{Xq}) \mathrm{Y}$ karyotype*}

SUMMARY A patient with Klinefelter's syndrome is described, in whom a $47, \mathrm{Xi}(\mathrm{Xq}) \mathrm{Y}$ karyotype $\mathrm{N}$ was established by trypsin-Giemsa and by BrdU acridine banding studies.

Several cytogenetic variants of Klinefelter's syndrome $\stackrel{\Phi}{\rightleftharpoons}$ have been described besides the most common 0 47,XXY condition. Most of them are represented by

*This work was supported in part by the Centro per l'Immunogenetica e l'Istocompatibilità of the Consiglio Nazionale delle Richerche (CNR). 